\title{
Mother-tongue education in a multilingual township: Possibilities for recognising lok'shin lingua in South Africa
}

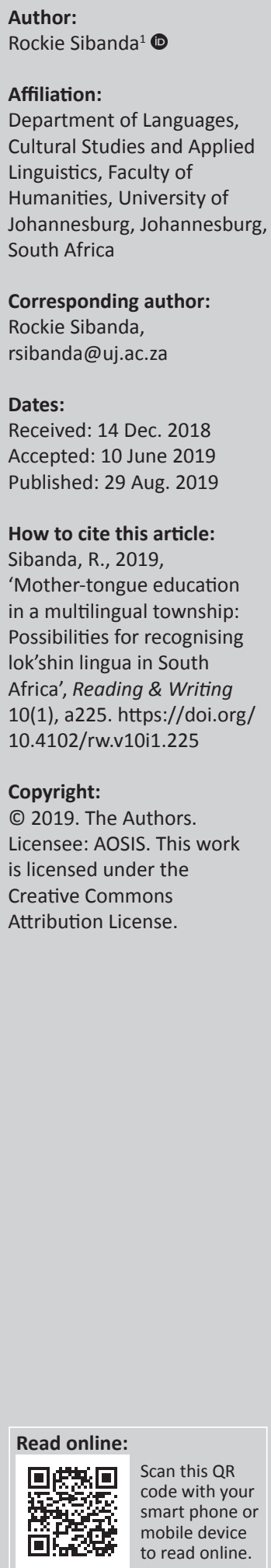

Background: Mother-tongue education in South African primary schools remains a challenge to policymakers. The situation is problematic in multilingual lok'shin (township) schools where the lok'shin lingua is not recognised as 'standard' language. This article raises the controversial possibility of positioning of lok'shin lingua in a formal education langscape.

Objectives: The article's first purpose is to highlight recent international and local research which depicts controversies surrounding mother tongue instruction in primary schools. The second purpose is to conceptualise lok'shin lingua as a dialect present in children's everyday vocabulary.

Method: Data was gathered through a qualitative approach using interviews. The interviews were conducted with parents and educators at a township in South Africa.

Results: Findings show notable differences in school language of instruction and the languages children speak outside school.

Conclusion: Mother tongue teaching is problematic as it is incongruent with learners' language repertoires. Therefore, a call is made for the recognition of lok'shin lingua in educational contexts as a way to promote more research into mother-tongue education.

Keywords: Dialect; home language; lok'shin lingua; langscape; township; mother tongue; multilingual; standard language.

\section{Introduction}

Mother-tongue education has been recognised as having potential benefits to young children's performance in school (Stoop 2017). Since South Africa attained independence in 1994, mothertongue education has been highly debated. The student protests at universities across the country in the past two and a half years, demanding among other things mother-tongue education, have occasioned provocative discussions on this issue. In South Africa, like elsewhere in the world, mother-tongue education is considered a fundamental human right (Trudell et al. 2012). This fundamental right is enshrined in Section 29(2) of the Constitution of the Republic of South (RSA 1996).

Research has shown that children's first language or mother tongue is the optimal language for literacy and learning throughout primary school (UNESCO 2008a). Over the years, De Varennes, a French-Canadian linguist has underlined the patent value of mother-tongue education, also highlighted by international research and international organisations such as the United Nations (Eloff 2017). For example, research done in Mali, between 1984 and 2000, showed that learners who received instruction in their mother tongue had a 32\% higher pass rate than those taught in French (Eloff 2017). Educationists have proposed that African language learners should be taught in their mother tongue for at least the first three years of school before switching over to English (Foley 2007). During those three years, English is taught as a core curricular subject. However, research has shown that it takes longer than three years to fully learn a language and recommends that children should learn through a language they know well for the first six years of schooling (Bloch cited in Cook 2013).

In South Africa, African language-speaking children are taught in their mother tongue for only three years, after which they switch to English in Grade 4. This switch foregrounds English 
as the 'main' language of learning and teaching (Madiba 2013). Under these circumstances, particularly in urban areas, mother-tongue education is highly contentious. This contention is partly due to the diverse language composition of urban populations. The languages spoken in the urban areas differ considerably from standard rural versions (Cook 2002; Matentjie 2010:40). The linkage in this discussion should concern mother tongue and lok'shin (township) lingua from the onset. This should reflect why, in this discussion, mother tongue theories foregrounded in this study are employed in essentially making a case for lok'shin lingua. Furthermore, the written forms of standard African languages remain in many ways archaic, limited and context-bound and seemingly incongruent with the modern scientific world (Foley 2007). As Foley (2007) further notes, the official African languages are only able to function as media of communication at such levels as interpersonal conversation. As they currently exist, standard written forms of the African languages have not yet been developed to the point where they can carry academic discourse effectively to function as full-fledged languages of learning and teaching, even at foundation phase level (Matentjie 2010). South Africa's major African languages do not have much literature that can facilitate effective classroom instruction. There are instances where teachers have to construct their own passages for comprehension tests (Venter cited in Cook 2013).

Taking the above argument into account, mother-tongue education seems to be a barrier to learners' progress in the early years of education. It can be argued that instead of enhancing classroom performance in township schools, mother-tongue education mostly advantages first language Afrikaans and English speakers in more affluent schools. For township learners, the standard African languages may in fact not be their native dialects (Cook 2009), whereas, as Owen-Smith (2010) notes, their English and Afrikaansspeaking counterparts use their own languages from Grade 1 to 12. The Progress in International Reading Literacy Study (PIRLS) report on literacy teaching and learning concurs with this observation, as it reveals that most of the learners who ostensibly performed best wrote the test in their home language (Eloff 2017; Spaull 2017). Poor academic performance in township and rural schools that is highlighted in PIRLS 2016 can be mainly attributed to teaching in a language different from what the children speak. As ongoing research shows, it is important to challenge the common assumption that mother-tongue education is necessarily helpful and empowering for African language speakers if it is based on the popular idea of what a 'mother tongue' is (Krause 2018). To explain this situation, Muller (2013) provides a useful and succinct summary of the language and learning complexities in schools. According to Muller (2013), when implementing mother-tongue education, the first critical mistake is the assumption that all schools are in the same situation, whereas they are not. In support of this observation, Setati and Adler (2000) point out that schools in rural areas have relatively homogenous language settings, whereas urban schools have diverse and very fluid langscapes. ${ }^{1}$ It can be maintained that this misconception largely accounts for the ineffectiveness and low academic achievement in rural and township schools.

To address the low academic achievement, proponents of mother-tongue education suggest teaching in the language that children speak at home (Krause 2018). The notion of the mother tongue refers to the codified standard version of standard African languages such as isiZulu, Setswana or Sesotho. These standard languages were transcribed in most cases by 19th century European missionaries, based on how they understood and conceptualised the way people spoke in the immediate vicinity of the rural mission stations (Krause 2018). Implementing mother-tongue education is problematic because it overlooks the variegated linguistic situation in South Africa. There is documented evidence of at least 25 different languages spoken in South Africa (Lemmer 2002) where the 11 official languages are just a proportion of the full range of tongues.

\section{Theoretical framework and literature review \\ Education models promoting mother-tongue education}

When considering schooling models that could work in South Africa, academics and policymakers often cite the 'immersion programmes' of French-Canadian schools (Genesee 2004; Lindholm-Leary \& Borsato 2006). The appropriateness of this model for the South African situation can be questioned for various reasons. Firstly, compared to South African learners, most of the learners attending FrenchCanadian schools come from homes with affluent socioeconomic backgrounds, where vocabulary and literacy practice in the mother tongue has had a strong foundation from the home (Genesee 2004). Secondly, these Canadian schools are staffed with truly bilingual teachers who are well trained in the practice of second language acquisition, even if they are content teachers (for example, mathematics and science). Thirdly, these schools are true immersion programmes where learners are not allowed to use their language at all, only French is allowed (Genesee 2004; Genesee \& Holobow 1989). Finally, the school day is extended with a rich variety of practices, both curricular and extracurricular, which are supported via well planned language development resources (Genesee 2004). Also from Canada is Cummins's (1981) widely cited work supporting arguments for mother-tongue education. This is also questionable, considering that South Africa has multiple mother tongues whereas the Canadian situation under which Cummins's additive bilingualism evolved has French and English (Banda 2010:61) as official languages, although Canada is a pluralist society with one of the most diverse national populaces.

Similar to Canada, South African is a pluralist society. For instance, in a typical township classroom one can find

1.The word 'langscape' is used by linguists to refer to the linguistic make up of a particular community, environment or place and purpose of language practice (Muller 2013) 
50 learners who speak 12 different mother tongues between them, especially in Gauteng (Muller 2013). Most of these learners are exposed to many languages spoken in their localities. Children from such multilingual settings are disadvantaged linguistically both at home and at school. At home their parents' mastery of home language and English or Afrikaans is usually relatively low and at school their educators struggle with English because they are not mother tongue English speakers. In many instances these teachers are often the only exposure to English that the learners have. This observation is not an indictment of teachers but of teacher training. An argument can therefore be made that the problem in township schools has as much to do with the medium of instruction as with classroom practice.

\section{Additive bilingualism}

Underpinning the current South African Language in Education Policy (LiEP) is the 'additive bilingualism' paradigm (Welch 2012). Theoretically, the LiEP recognises the importance of mother tongue instruction for at least the first six grades as an essential step in ensuring the development of literacy and numeracy. However, in reality mother tongue instruction only happens in the first three years of schooling, then there is a switch to English, or Afrikaans to a lesser extent, in Grade 4 (Taylor \& Coetzee 2013). In 2009, the commission set up by the Department of Basic Education reported the transition to English in Grade 4 as problematic (Department of Basic Education 2010). Surprisingly, the commission recommended that English should be introduced even earlier, in Grade 1, arguing that it would facilitate a better transition (Owen-Smith 2010:32). This recommendation suggests that a small amount of English acquired by learners over three years should be sufficient to facilitate a switch to English in Grade 4 (Owen-Smith 2010:32). For example, the Threshold Project, conducted in South Africa, showed that many black learners had difficulty adjusting to the switch from mother-tongue education to the English medium of instruction in Standard 3 (Grade 5). The research found that learners could not transfer knowledge acquired in the first language to English nor vice versa (Hoadley 2012:189).

Although children who have little exposure to second language may be better prepared for school, they will need ongoing support to acquire sufficient proficiency in it. Lightbown (2008) warns that becoming completely fluent in a second language is not as easy as many people have claimed, but rather it takes several years. Nicholas and Lightbown (2008) explain that the pace of learning an additional language, and the effective instruction or support for children to learn an additional language, depends upon whether the child has developed literacy in the first language. It is argued that in order to succeed in academic subjects, children need to continue developing their first language (Lightbown 2008).

\section{Subtractive bilingualism}

In contrast to the additive bilingual approach is the subtractive or immersion approach. In this approach mother tongue is initially used as a medium of instruction but it is soon replaced with the target language, which, in the South African context, is predominantly English (Alexander 2006). In the South African context, the complete immersion model seems impractical because of certain contextual factors. Firstly, there are no resources for this model in South African schools. Secondly, only $8 \%-9 \%$ of South African population are first language English speakers (StatsSA 2015). Many of these first language speakers are not interested in becoming teachers. They do not find teaching as more appealing and lucrative than other options often available to them (Muller 2013). Therefore, children are taught by many South African teachers who are not mother tongue English speakers and struggle with English themselves (Muller 2013).

The common subtractive bilingual model or approach is the 'straight-for-the-target language' (Heugh 1993) approach where, in the South African context, non-English-speakers are taught in English from preschool. However, both local and international research clearly shows that 'subtractive (straight for L2) and early transition programmes do not facilitate successful results' (Heugh 2005a:65-66). Early immersion in a second language (L2) is considered detrimental to the cognitive growth and literacy development of the learner (Heugh 2005b). The long-term effect of subtractive bilingualism is that learners eventually regress in both languages and, even worse, can lose their home language's cognitive and academic proficiency skills (Baker 2006; Cummins 2008). The direct consequence of this is that the learner's language proficiency, in a sense, does not develop beyond the basic interpersonal communicative skills (BICS) level.

\section{Mother-tongue education}

The sociopolitical problems underlying mother-tongue education in South Africa date back to the apartheid era. The apartheid nationalist government policy to preserve ethnic identities went to the extent of attempting to create monolingual societies out of multilingual South Africa (Banda 2010). Apart from separating people according to race and language group, the apartheid regime insisted on mother-tongue education which was flawed for various reasons. Firstly, although 11 official languages are recognised in South Africa, only Afrikaans and English were (and are still) accorded higher status. Secondly, literature shows that typically a South African uses at least two languages depending on context. Black people, particularly those in urban areas, have been known to use three or more languages (De Klerk 2002; Slabbert \& Finlayson 2000). In most South African contexts, it is likely that the child's home language will be one or more local or regional dialects, sociolect or non-standard variety different from the written standard (Plüddemann 2010:6). These children are unable to perform academically in standard language because they have surface-level fluency in their home language.

In order to address the language problems in education, government enacted the LiEP (Department of Education 1997), 
within which there is provision for schools to determine their own language policy in consultation with the parents and the community (Ncoko, Osman \& Cockroft 2000). Although, the LiEP gives parents the right to choose the language through which they want their children to be taught (Department of Education 1997), the power to determine the language policy of a school rests with the school governing bodies (SGBs). The interpretation of this provision has been the object of significant legal contestation, as is evidenced by the number of court cases pertaining to language policies in Afrikaans medium schools in particular. For example, in the case between the SGB and Rivonia Primary School versus Member of the Executive Council (MEC) for Education, Gauteng Province and Others, contestations over the admission policy and school capacity were highlighted (Mestry 2017). Although, well intended, the implementation of the LiEP has thus far been ineffective (Van Staden, Bosker \& Bergbauer 2016) because it fails to address the complex situation where schools teach in a language that is nonetheless different from what the learners speak at home (Howie, Venter \& Van Staden 2008). This presents problems in implementing mother-tongue education in a language that children identify with; hence, a case for the recognition of lok'shin lingua can be made. Arguably, lok'shin lingua is part of township identity. It is the lingua of cognition in which learners interact and form concepts for self-expression, facilitating learning.

\section{Research method and design}

\section{Site}

The current study takes place in Kagiso, a multilingual township ${ }^{2}$ in the western part of the Gauteng province of South Africa. The diverse multilingual composition of Kagiso township is a result of the current political and socio-economic conditions in South Africa. The advent of independence in South Africa in 1994 allowed free movement of people within provinces. Gauteng, considered to be the economic hub of South Africa, experiences an influx of migrants from other provinces because people seek employment opportunities in Johannesburg and Pretoria and their surrounding areas. The migrants from other provinces, in particular, bring into Gauteng different local languages that are predominantly spoken in other provinces. Kutlwano Primary School, ${ }^{3}$ where the research participants are drawn from, is one of the six primary schools located in Kagiso. At the time the initial study was conducted, only Setswana and isiZulu were the languages of learning and teaching in the foundation phase (Grades R-3) and there is a switch to English in the intermediate phase (Intersen Phase). ${ }^{4}$ The learner population in this primary school comprises only black children from multilingual backgrounds, reflecting the cultural and linguistic diversity in the township.

2.Designated residential areas for black and mixed race people under the Group Areas Act 1950, during the apartheid years.

3.A pseudonym used to protect the identity of the school and participants.

4.Intersen is a combination of INTERmediate and SENior phases where Intermediate is Grade $4-6$ and Grade 7 is senior.

\section{Research methods of enquiry}

This article is part of a larger study that examined early childhood literacy practices in a multilingual township. A qualitative research design with a case study approach was used to guide the study of early childhood literacy practices of Grade 3 children in Kagiso township in the west of Johannesburg, South Africa. Data was collected over a period of 9 months, through in-school and out-of-school observations, interviews and conversations with educators and family members of learners who participated in the study. This research approach presented opportunities to develop an in-depth account of meanings of literacies of young learners. It also supported the need to understand how language and social context transect to promote comprehensive classroom instruction and literacy development, particularly in the foundation phase. The aim of the broader case study was to explore early childhood literacy practices in a multilingual township. However, the current study was not the initial aim of the broader case study but a result of an incidental finding; as such a research question emerged: How can research on mother tongue instruction help to recognise lok'shin lingua as standard dialect across a range of contexts, including school?

\section{Data presentation, analysis and interpretation Interviews with teachers}

\section{Pen portrait 1: Ms Hamba the disciplinarian}

Ms Hamba is a foundation phase teacher at Kutlwano Primary School. She is in her early 50s and has been teaching the foundation phase for more than 30 years. She teaches one of the three Setswana medium classes. Although Setswana is not her mother tongue, she is fluent in Setswana as she grew up in Mahikeng in the North West, a predominantly Setswana-speaking province. She is married to a Setswanaspeaking husband. Her loud and authoritative voice seems to instil strict discipline in her class. She makes learners who do not do their homework or misbehave in class do their school work while kneeling or squatting on the floor for the entire $30 \mathrm{~min}$ of the lesson.

\section{Vignette 1: Ms Hamba}

Interviewer: What seems to be the problem?

Ms Hamba: The problem is mother tongue. Learners have a very weak foundation in mother tongue.

Interviewer: Does this apply to both home language and English?

Ms Hamba: The isiZulu or Setswana they learn in class differs from what they speak at home. I think their home language is affected by their environment.

Interviewer: What is wrong with their environment? Ms Hamba: You find that the father of the child is Tswana and the mother is Venda and the child plays with Zulu children. The child gets confused. These children don't understand even their home language. They don't have a proper home language.

Interviewer: How then do they learn? 
Ms Hamba:

Those from good crèches learn much better in English but they have problems when they learn in Setswana in foundation phase.

Interviewer: What happens with those who are not from good crèches?

Ms Hamba:

Those experience serious problems in English, especially in Grade 4 when they switch to English only. English is foreign to them. It is white people's language for Model Cs. ${ }^{5}$

This extract epitomises the complexities of multilingualism in the Gauteng schools. As Ms Hamba points out, it is probably extremely difficult for township children to have a solid foundation of home language because of the mixed language setting in their families. This leads them not to have a 'proper home language'. As Ms Hamba indicates, the isiZulu or Setswana that children learn in class differs from what they speak at home, because that is mostly a mixture of different languages. Arguably, nothing is wrong with the children's mother tongue, but the problem is the notion of 'mother tongue'. Drawing on Krause's (2018) provocative comment, claims can be made that today's African languages and so-called mother tongues are not defined by the way urban dwellers speak but by how white missionaries codified them decades ago.

Ms Hamba observes that children who attended 'good crèches' (preschools) speak 'good English' while those who did not attend good ones lack English proficiency, which is assumed to be predictor for success. Although children from 'good' crèches or preschools are said to speak better English, they experience problems in Setswana. What seems problematic is their early exposure to English in crèches that use the straight-for-target language (English) approach (Ball 2014). The straight-for-English approach may make children lack competence in their home language (Ball 2014), leading to poor mastery of both English and the mother tongue (Banda 2010:51). English is also associated with race and social class, as Ms Hamba terms it: 'white people's language for Model Cs'. The former Model C schools denote both race and class superiority mostly associated with white people and the black middle class. The educators' preference of English seems to support English dominance and neglect of African languages. However, this preference for English instruction can be problematic for different reasons. Firstly, most educators in township schools are essentially products of an inferior Bantu education system and they lack English proficiency (Christie \& Collins 1979). For example, interview transcripts of educators in this study were found to be riddled with several language errors ranging from incorrect use of tense to unintelligible sentence fragments. It seems impractical to expect educators who themselves are not confident and proficient in English to teach learners in that language. Based on this observation of the educators' lack of language proficiency, one could ask whether the problem in township schools is a result of learning or teaching.

5.Schools meant for white children before 1994.

\section{Pen portrait: Ms Fakude the pure Zulu}

Ms Fakude is a foundation phase teacher with 20 years of teaching experience. She is a Zulu mother tongue speaker from KwaZulu-Natal, a predominantly isiZulu-speaking province in South Africa. She prefers to be interviewed mainly in isiZulu (parts of the transcript have been translated to English). Ms Fakude teaches one of the two isiZulu medium Grade 3 classes.

\section{Vignette 2: Ms Fakude}

Interviewer: Usho ukuthi abamuzwa utisha uma ekhuluma i-Setswana noma isiZulu? [You mean learners don't understand when a teacher speaks Setswana or isiZulu? (author's own translation)]

Ms Fakude: Ulimi lwebele alufani nolimi lwasekhaya. Lufuna umuntu oluncelile. Njengoba uzwa uma ngikhuluma, mina ngingumZulu phaqa, waseNatal. Ozakwethu laba abazalelwe lana eGoli bakhuluma isiZulu sasemalokishini. Inkinga njalo yikuthi isiZulu sibanzi njalo siyahlukana izigodi nezigodi. Amanye amagama aso ajulile. [Mother tongue is different from home language. It needs one who is born with it. As you can hear when I speak, I am a pure Zulu from KwaZulu-Natal. My colleagues born here in Johannesburg speak township Zulu. The other problem is that Zulu is so broad and differs from one area to another. Some of the Zulu words are very deep (author's own translation)].

Interviewer: How does all this affect the children you teach? Ms Fakude: It's a pity for my young learners who are exposed to the wrong Zulu and many other languages at a very young age. They mix Zulu with other languages such as Setswana, Xhosa or Swati. They tend to throw in a lot of Xhosa and Swati words partly because they think it is cool and mainly because those languages resemble Zulu. Here in Kagiso they've their own Zulu dialect. Ngempela angazi ukuthi yini abayikhulumayo [Honestly, I don't know what (language) they speak (author's own translation)].

Interviewer: Is this Zulu dialect acceptable in the classroom? Ms Fakude: Although this dialect differs in accentuation from the one spoken in KwaZulu-Natal (KZN), I think it should be accepted here in Gauteng as another version of the standard language. Because even in KwaZulu-Natal many different varieties are spoken from place to place.

Interviewer: When you teach content subjects in Zulu are your learners able to grasp key concepts?

Ms Fakude: That is a major problem because isiZulu, like other African languages, borrows a lot from English and Afrikaans as we do not have Zulu equivalents for some words.

In Vignette 2, there is evidence that Ms Fakude prides herself of being a 'pure Zulu' from KwaZulu-Natal. By using belittling terms such as 'township Zulu' and 'wrong Zulu', it is apparent that she disparages the 'inferior' form of Zulu spoken in Johannesburg. Although she despises her colleagues' inferior Zulu, 'isiZulu sasemalok'shini' [township Zulu], she acknowledges the existence of different Zulu 
dialects even in KwaZulu-Natal. Donnelly (cited in Dowling 2011:362) sheds light on the existence of important subvarieties of several national languages in South Africa where children who speak Mpondo, Bhaca, Cele and other smaller Nguni' languages, are 'forced to declare themselves arbitrarily as "Xhosa" or "Zulu," even where these "dialects" are mutually unintelligible with the standard language'. According to Ms Fakude, township dwellers speak isiZulu mixed with other languages. Findings of the current study show that many households in townships are multilingual which is problematic to mother-tongue education, as De Klerk (2002), notes:

Many South Africans, especially those in urban areas, are highly multilingual, and it is often difficult to identify a single first language for a particular child or assess children's proficiencies in the languages they speak. (p. 38)

As Ms Fakude admits that isiZulu is localised, she suggests recognition of township isiZulu as another dialect, just as the different isiZulu dialects spoken in KwaZulu-Natal are recognised.

\section{Interviews with parents}

\section{Pen portrait 3: Mr Miya speaking his mind}

Mr Miya is a parent of one of the five learners participating in the initial study. He is isiXhosa speaking while his wife is Setswana speaking. In his home, he prefers using Setswana with his family. As a general worker in a factory, Mr Miya is rarely at home because he works long hours. He usually leaves for work when his children are still asleep and returns when they are already in bed. Besides his busy schedule, Mr Miya actively participates in the affairs of the school where this study is conducted. He is the chairperson of the SGB, which among its main functions decides on the language policy of the school. Mr Miya is very opinionated on school curriculum issues and other matters concerning the school. He is also doing distance learning studies in Theology at the University of South Africa.

\section{Vignette 3: Mr Miya}

Interviewer:

Why do you say children don't understand when teachers speak pure Setswana?

Mr Miya: $\quad$ Teachers in this school teach a North West type of Setswana. Setswana has different dialects which are problematic. You can speak North West Setswana and I speak Gauteng Setswana. What is written in books is pure Setswana. Because I'm used to my second grade Setswana, the book Setswana seems different.

Interviewer: $\quad$ Does it mean that children don't understand the standard Setswana written in the books?

Mr Miya: Yes, that's what I mean. In the whole of Kagiso we've our own style of speaking Setswana. You go to Mohlakeng, they've their own style of speaking Tswana. You go to Carletonville and Khutsong, they speak their own different type of Setswana. Even in Zeerust, Mafikeng and

6.Languages including isizulu, isiXhosa, siswati and isiNdebele.
Rustenburg, they speak different Setswana. You go to Taung, Klerksdorp, Kimberly, their Tswanas are not the same. I don't have to like pure Tswana but it has to be taught properly. If our children are not taught their own language, it will die. The next generation won't even know this language.

Interviewer: Does it mean that some of the teachers don't know the language?

Mr Miya: $\quad$ Their approach to teaching is wrong. I may not be eloquent in pure Tswana but I make an effort to learn. Teachers must learn real Setswana from pure Batswana. There are many pure Tswana speakers in our township that speak real Tswana. Ke buwa ka bo mafikizolo ba mo kasi a bareng 'nna ke Motswana tota' [I mean those new arrivals in the township who say, 'I am a real/pure Motswana' (author's own translation)]. Some teachers are just afraid to learn pure Tswana from an ordinary person. They think that uneducated people will not take them seriously. Those uneducated people are the ones who know the real language, the idioms and all those things.

Interviewer: What is your definition of being educated?

Mr Miya:

Education is not books. My mother seated there could know a lot more about my Xhosa language than a professor of Xhosa who knows what he just reads in books. She may know folk songs and their meanings and different Xhosa rituals, which form our culture and language, which educated people don't take seriously. So the teachers don't learn from the people who have got the knowledge and the know-how.

Interviewer: What do you think about materials such as books and worksheets that are used in schools?

Mr Miya: Most of the words in the Department of Education books are not written in standard Tswana. They're just written in township streetTswana.

Interviewer: So how are teachers linked to this? Mr Miya: If teachers see errors, they must correct them so that they teach children the right thing. Since our teachers don't know the right language, they teach our kids wrong Tswana, which means our children balimele [are doomed (author's own translation)]. Government must rethink the issue of standard language. Yes, we must protect our language but we can't be judged on rural language in this day and age.

In Vignette 3, Mr Miya describes standard Setswana using terms similar to those of Ms Fakude: 'pure' and 'real'. These terms seem to denote authenticity. In his view, township Setswana is 'wrong', 'second grade', 'Gauteng Setswana' as compared to 'North West Setswana'. Mr Miya's remarks exemplify the intricate complexities of the diverse Setswana structure located not only within the multilingual Gauteng townships, but in South Africa as a whole. Standard Setswana taught in school is positioned in physical space based on different regional dialects spoken in South Africa. An interesting aspect from this extract is the difference between the Afrocentric and Western conceptualisation of standard language: while in the West standard language is associated 
with middle class and higher education levels (Trudgill 1974), in Africa it is associated with rural populations (Deumert 2005; Mesthrie 2002), most of whom might not even have any formal education. To accommodate the changing language forms, Mr Miya suggests a review of standard languages to incorporate the evolving dialects. If Mr Miya's view is to be taken into consideration, reviewing the standard languages could be a costly and lengthy process requiring commitment from academics, cultural groups, government departments and bodies such as PanSALB. A question has to be posted on how far the review could go without completely annihilating the standard languages which are the pride and sense of identity of many South Africans.

\section{Pen portrait 4: Ms Zungu the Gauteng Zulu}

Ms Zungu is the aunt and guardian of Thandi, one of the learners participating in the initial study. She has a high school level of education and a qualification in hospital auxiliary service which involves assisting patients in hospitals. Ms Zungu speaks freely about her background and gives insight into Thandi's life and the activities that she engages in at home. She seems interested in the education of her daughters, Mpho and Thandi. Ms Zungu outlines the challenges that her children face at school, particularly with Setswana and isiXhosa, and describes the nature of assistance they get. Ms Zungu is isiZulu speaking and prefers having the interview in isiZulu.

\section{Vignette 4: Ms Zungu}

Interviewer: $\quad$ How are the children progressing in school?

Ms Zungu: Thandi has problems with Setswana because it is not our home language. If she fails Home Language she won't proceed to the next grade. The Setswana that she does at school is not our language. Here in this house we speak township Zulu. She doesn't even know how to count from 1 to 20 in Setswana. Whenever she has problems she seeks help from others.

Interviewer: In which language do they learn?

Ms Zungu: $\quad$ Thandi is in Grade 3 so she does all her subjects in Setswana, except the English subject. Mpho is Grade 6 so she does all hers in English and does Xhosa as a subject. By the way when Mpho started Grade 1, the school was supposed to offer Xhosa, Zulu and Setswana. She was put in Xhosa class because the Zulu class was cancelled as there was no one to teach it.

Interviewer: How important is Setswana and isiXhosa?

Ms Zungu: In order to be promoted to the next grade they must pass both the African languages and English. Mpho failed last term, in March, because she got a level 3 [40\%] in isiXhosa. Although she had levels $6 \mathrm{~s}[70 \%]$ and $7 \mathrm{~s}[80 \%+]$ in all other subjects. She cried and said, 'Mum I did well in all other subjects but I failed Xhosa because we do it only once a week'.

Interviewer: What do you do when Thandi needs help with Setswana?

Ms Zungu: Thandi gets help from my brother's wife, Ipotseng. Ipotseng is originally from Rustenburg and speaks pure Setswana. My mum can also speak Setswana because she attended a Roman Catholic school (where Setswana was the lingua franca) but Mum is a local girl. I'm also a local girl. Although Mum did Setswana at school, she struggles to help Thandi because the level of Setswana in these kids' books is too high.

Interviewer: Who helps Mpho with Xhosa?

Ms Zungu:

Mpho usually gets help from our neighbour, Noma. You see, Noma is a pure Xhosa, straight from Eastern Cape. Ukhuluma isiXhosa sasemakhaya [She speaks rural Xhosa]. Although she works, she helps Mpho when she is available, even at night.

Interviewer: What did you mean when you said you and your mum are local girls?

Ms Zungu: $\quad$ Oh, I mean that we were born in the township. You see, I am Zulu but I don't speak the KZN Zulu. I speak township Zulu. People born here in the township speak many different languages although they may not be fluent in them.

Two important issues pertaining to language emerge from this extract: the issue of progression and promotion and the linguistic background of learners. According to the current policy on promotion and progression in primary school, learners are required to pass both the home language and first additional language. Ms Zungu finds mother tongue difficult for her children who speak a different language at home. Mpho's problem seems to be the school's overemphasis on English and neglect of Xhosa which is taught by a non-Xhosa speaking teacher who is not fluent in the language. Mpho also alleges that Xhosa is taught only once a week although it is a critical subject which suggests a lack of commitment by the school in teaching the subject. Since the initial study did not focus on Grade 6, Mpho's allegation could not be verified. Of importance, Ms Zungu uses the term, 'local girl', priding herself on her township identity which is associated with a sense of belonging and her lok'shin lingua. According to Ms Zungu, township dwellers speak many languages although they may not be fluent in any of them. However, Ms Zungu claims that her mother is fluent in Setswana, which she attributes to her attendance at a Roman Catholic school. This rationale is somewhat flawed because it cannot be that her ability to speak Setswana is only attributable to her attendance of a Roman Catholic school. Not everyone who attended a Catholic school is able to speak Setswana. Besides the possibility of the medium of instruction or lingua franca at the school being Setswana, there could be additional contributory factors such as regular interaction in Setswana in her environment.

\section{Discussion}

Two key themes emerge from the data: the relevance of ruralbased standard languages and possibility for urban lok'shin lingua in mother-tongue education.

\section{I am a pure Zulu (Mina ngingumZulu phaqa): Relevance of rural-based standard languages}

One of the key themes emerging from these extracts is the issue of language and identity. Ms Fakude finds speaking 
'pure' Zulu an important aspect of her sense of identity as opposed to inferior 'Johannesburg Zulu'. According to Hodgson (2002), people who speak isiZulu that is not mixed with other languages are regarded ambassadors of their language. Ms Fakude draws attention to her pronunciation and accentuation of isiZulu. As in the findings made by Nongogo (2007), Ms Fakude foregrounds her 'pure Zulu' ethno linguistic identity in her remark, 'Njengoba uzwa uma ngikhuluma, mina ngingumZulu phaqa, waseNatal' [As you can hear when I speak, I am a pure Zulu from KwaZulu-Natal]. This common remark among isiZulu-speaking people denotes a sense of pride and 'ethnic purity', as highlighted in words such as 'pure', 'original', 'real'. Ms Fakude's remarks show her uncompromising rigidity towards mother tongue education as Dowling (2011:346) observes: 'African language teachers generally regard any questioning of the "standard," static varieties of African languages as tantamount to racism and as disrespectful of the culture'. She expresses concern that her colleagues teach learners 'wrong Zulu'. In a separate interview she laments the destruction of mother tongue and calls for its preservation: 'Azibuyele emasisweni' [Let's go back to our roots]. Her call is consistent with many linguistic groups calling for the need to ensure that the youngest members of their communities keep their linguistic heritage through mother-tongue education (Ball 2014). A corpus of examples produced by UNESCO (2008b) attests to growing interest in promoting mother tongue-based education, and to a wide variety of models, tools and resources being developed and piloted to promote learning programmes in mother tongue education. Despite her conservative stance, Ms Fakude calls for recognition of lok'shin lingua as an official dialect.

\section{I speak Gauteng Setswana: Possibility for urban lok'shin lingua}

Mr Miya's remark, 'I speak Gauteng Setswana', identifies a language form with an urban geographical space. He admits to speaking an inferior Setswana that he describes as 'second grade'. Mr Miya highlights the relationship between language and identity where the urban dialects are associated with 'urbanness' or being modern. For example, he uses the demeaning term 'bo mafikizolo' [new arrivals] to describe those who speak the so-called standard language which, according to township perceptions, is not 'up-todate' with the modern township lingua. Studies on the emerging urban forms of African languages done elsewhere in Africa have shown that the younger generation finds more status and prestige in the urban varieties than the rural-based standardised languages (Banda 2010). Although Mr Miya admits to speaking Gauteng Setswana, he does not condone its fallibility. Although he advocates teaching of proper Setswana in order to preserve its existence for the future generation, he calls for a review of standard languages to meet urban contexts. It is possible that these township dialects have evolved to accommodate social and technological developments that more isolated linguistic contexts preclude, so speakers mix languages where there are no equivalent isiZulu terms.
In conclusion, the current standard languages are considered irrelevant to the current linguistic structure. Urban dwellers associate them with ruralness and backwardness. In stark contrast to this perception is the pride of upholding standard languages. For example, Ms Fakude says 'mina ngingumZulu phaqa' [I am a pure Zulu], a common term among proud isiZulu speakers. Similarly, Mr Miya cites an equivalent term used by the Batswana who are proud of their language, 'nna ke Motswana tota' [I am a real/pure Motswana]. Featuring in both isiZulu and Setswana articulation is the emphatic first person: 'mina' and ' $n n a$ '. This highlights a sense of pride in one's identity. These expressions of Zulu-ness and Tswananess affirm pride in one's ethnicity (Nongogo 2007).

\section{Pedagogical implications and conclusions}

From the data, what seems problematic is the over-emphasis on spoken mother tongue as the sole predictor for success in school. Evidence from research shows that exposure to more complex lexicons and grammar is through reading, not just speaking. For example, Macdonald's (1990) case study found that the Setswana-speaking learners' insufficient grasp of the linguistic structure of English seriously limited their ability to read (and particularly to read for meaning) in English. Thus, Spaull (2016:3) points out that 'children who have not learnt to read cannot read to learn'. Therefore, the ability to produce written texts to develop literacy is related to reading and comprehension as research reveals that the ratio of new vocabulary in writing is three times more than that used in spoken conversation (Spaull 2017).

As has been highlighted, spoken language proficiency on its own does not always lead to success in school. There seems to be a correlation between achievement and ability to read for meaning. The PIRLS 2016 results show that learners who had very poor test scores in indigenous African languages were unable to read for meaning (Spaull 2017). Besides the inability to read for meaning, poor performance in African languages can be attributed to other factors such as shortage of African language textbooks and poor comprehension skills. Most textbooks are only available in English, which children cannot read for comprehension. There is also evidence of poor classroom practices as most teachers who lack confidence in their subjects depend heavily on textbooks, particularly in content subjects. Instead of improving the pedagogical ability of teachers, government seems obsessed with provision of textbooks. A typical example is the Limpopo textbook saga in which failure to deliver textbooks in schools has been a debatable issue.

Data from the study suggests that the language forms or dialects of children do not just disappear in the townships but emerge in the classroom. This calls for the recognition of each dialect as constituting a well-developed linguistic system with its own rules for variations from the standard language. In other words, speakers of dialects express linguistic differences, not linguistic defects as mostly assumed by schools 
(Pearson \& Stephens 1994:33). In the process of making each individual learner a speaker of standard language, schools could eradicate a particular dialect (Pearson \& Stephens 1994:33). Evident in the current study is the existence of dialects or language forms in South Africa that are defined by geographical locations. In pursuit of recognition of townships as geographic locations with a recognisable language structure the following question is posed: How can research on mother tongue instruction help to recognise lok'shin lingua as a standard dialect across a range of contexts, including school?

This pedagogical challenge requests elevation of township lingua to a recognised dialect. Given the South African context, the concept of 'mother tongue' is increasingly becoming ambiguous and flawed considering the ruralurban migration and the changing langscape (Slabbert \& Finlayson 2000; Webb 2009). The supposedly 'pure' languages are found to bear only a loose family resemblance to the way modern people in both rural and urban areas actually speak. We have to accept the distinctive dichotomy separating ruralbased dialects from their urban varieties. A call for regional language education would be more appropriate as it would mean recognising the urban lok'shin lingua as a 'regional dialect' that could be more functional in implementing a comprehensive Mother-tongue education for urban learners.

\section{Acknowledgements Competing interests}

The author declares that there is no financial gain or personal relationship with participants or other parties that may have had inappropriate influenced the writing of this article.

\section{Author's contributions}

R.S. collected and analysed the data and put the paper together to meet the requirements of Reading $\mathcal{E}$ Writing journal.

\section{Ethical consideration}

This article followed all ethical standards for carrying out research without direct contact with human or animal subjects.

\section{Funding}

This research received funding from the Faculty of Humanities Research Fund.

\section{Data availability statement}

Data sharing is not applicable to this article as no new data were created or analysed in this study.

\section{Disclaimer}

Views submitted are the author's and not an official position of any institution or funder.

\section{References}

Alexander, N., 2006, 'Draft paper: Language medium policy and practice as barrie to quality education', viewed 07 December 2016, from http://www.cedol.org/ cgibin/items.cgi?rm200612141220462016.

Baker, C., 2006, Foundations of bilingual education and bilingualism, 4th edn., Multilingual Matters Ltd, Clevedon.

Ball, J., 2014, Children learn better in their mother tonque: Advancing research on mothe tongue-based multilingual education, viewed 08 March 2016, from https://www. globalpartnership.org/blog/children-learn-better-their-mother-tongue.

Banda, F., 2010, 'The dilemma of the mother tongue: Prospects for bilingual education in South Africa', Language, Culture and Curriculum 13(1), 51-66. https://doi.org/ 10.1080/07908310008666589

Christie, P. \& Collins, C., 1979, 'Bantu education and the reproduction of apartheid ideology', in P. Kallaway (ed.), Apartheid and education, pp. 59-75, Ravan, Johannesburg.

Cook, M.J., 2013, South Africa's mother tongue education challenge, viewed 12 September 2018, from http://www.mediaclubsouthafrica.com/youth-andeducation/ 43culture/culturenews/3555-south-africa-s-mother-tongue-education-problem\# ixzz5VwqD8ViY.

Cook, S.E., 2002, 'Urban language in a rural setting: The case of Phokeng, South Africa', in G. Gmelch \& W.P. Zenner (eds.), Urban life: Readings in the anthropology of the city, 4th edn., pp. 106-114, Waveland Press, Prospect Heights, IL.

Cook, S.E., 2009, 'Street Setswana vs school Setswana: Language policies and the forging of identities in South African classrooms', in J. Kleifgen \& G.C. Bond (eds.), The languages of Africa and the diaspora: Educating for language awareness (New Perspectives on Language and Education, 12), pp. 48-65, Multilingual Matters Ltd, Bristol.

Cummins, J., 1981, 'The role of primary language development in promoting educational success for language minority students', in California State Department of Education (ed.), Schooling and language minority students: A theoretical framework, evaluation, dissemination, and assessment center, pp. 3-49, California State University, Los Angeles, CA.

Cummins, J., 2008, 'BICS and CALP: Empirical and theoretical status of the distinction', in B.V. Street \& N.H. Hornberger (eds.), Encyclopaedia of language and education literacy volume 2, 2nd edn., pp. 71-83, Springer Science Business Media LLC, New York.

De Klerk, G., 2002, 'Mother tongue education in South Africa: The weight of history', International Journal of the Sociology of Language 154, 29-46. https://doi.org/ 10.1515/ijsl.2002.01

Department of Basic Education, 2010, The status of the language of learning and teaching (LoLT) in schools: A quantitative overview, Department of Basic Education, Pretoria.

Department of Education, 1997, Language in education policy, section 3(4) $(\mathrm{m})$ of the National Education Policy Act, 1996 (Act 27 of 1996), National Department of Education, Pretoria.

Deumert, A., 2005, 'The shape of the standard - Reflections on post-colonial standard languages, with special attention to South Africa', in V. Webb, A. Deumert \& B. Lepota (eds.), The standardisation of African languages in South African languages in South Africa, pp. 17-34, PanSALB, University of Pretoria.

Dowling, T., 2011, “'Stressed and sexy": Lexical borrowing in Cape Town Xhosa', International Journal of Multilingualism 8(4), 345-366. https://doi.org/10.1080/14 790718.2011.604128

Eloff, T., 2017, We neglect mother tongue education at our peril, viewed 10 October 2018, from http://www.politicsweb.co.za/opinion/the-elephant-in-the-roommother-tongue-education.

Foley, A., 2007, 'Mother tongue education in South Africa. Chapter in English and multilingualism in South African society', Papers from the English National Language Body of PanSALB, 02 February, viewed 02 September 2018, from http:// www.englishacademy.co.za/pansalb/education.pdf.

Genesee, F., 2004, 'What do we know about bilingual education for majority language students', in T.K. Bhatia \& W. Ritchie (eds.), pp. 547-576, Handbook of bilingualism and multiculturalism, Blackwell, Malden, MA.

Genesee, F. \& Holobow, N., 1989, 'Change and stability in intergroup perceptions', Journal of Language and Social Psychology 8, 17-38. https://doi.org/10.1177/ $0261927 \times 8900800102$

Heugh, K., 1993, 'Not so straight for English', Bua! 8(2), 31.

Heugh, K., 2005a, 'Theory and practice - language education models in Africa: research, design, decision-making, outcomes and costs', draft chapter for a report Optimising Learning and Education in Africa: the Language Factor commissioned by ADEA, pp. 63-101, GTZ, Commonwealth Secretariat.

Heugh, K., 2005b, 'The merits of mother tongue education', SA Reconciliation Barometer 3(33), 8-9.

Hoadley, U., 2012, 'What do we know about teaching and learning in South African primary schools?', Education as Change 16(2), 37-41. https://doi.org/10.1080/168 23206.2012.745725

Hodgson, L., 2002, 'Exploring changing identities: A case study of black female technikon students' understanding of themselves as users of English, and as users of other languages', M.A. thesis, School of Languages Culture and Communication, University of Natal, Pietermaritzburg.

Howie, S.J., Venter, E. \& Van Staden, S., 2008, 'The effect of multilingual policies on performance and progression in reading literacy in South African primary schools', Educational Research and Evaluation 14(6), 551-560. https://doi.org/10.1080/ 13803610802576775 
Krause, L., 2018, It's time to rethink what's meant by 'mother tongue' education viewed 21 May 2018, from https://www.news. uct.ac.za/article/-2018-05-21-itstime-to-rethink-whats-meant-by-mother-tongue-education.

Lemmer, E.M., 2002, 'Fostering language development in multicultural schools in South Africa', Educare 31(1), 38-62.

Lightbown, P., 2008, 'Easy as pie? Children learning languages', Concordia Working Papers in Applied Linguistics 1, 1-25.

Lindholm-Leary, K.J. \& Borsato, G., 2006, 'Academic achievement', in F. Genesee, K. Lindholm-Leary, W. Saunders \& D. Christian (eds.), Educating English language learners, pp. 157-179, Cambridge University Press, New York.

Macdonald, C., 1990, Crossing the threshold into standard three. Main report of the threshold project, Human Sciences Research Council, Pretoria.

Madiba, M., 2013, Report for Umalusi: Academic literacy at foundation phase level an exploratory investigation report, Multilingualism Education Project Centre for Higher Education Development Funder, UMALUSI, Pretoria.

Matentjie, T., 2010, Mother tongue instruction, viewed 08 October 2016, from https:// hsf.org.za/publications/focus/focus-56-february-2010-on-learning-and-teaching/ mother-tongue-instruction.

Mesthrie, R., 2002, 'South Africa: A sociolinguistic overview', in R. Mesthrie (ed.) Language in South Africa, pp. 11-26, Cambridge University Press, Cambridge.

Mestry, R., 2017, 'A critical analysis of the learners' constitutional rights to basic education in South Africa', KOERS - Bulletin for Christian Scholarship 82(3), 1-12. https://doi.org/10.19108/KOERS.82.3.2327

Muller, S., 2013, Thoughts on mother-tongue based education, viewed 18 Novembe 2018, from http://mzansimaths.blogspot.com/2013/10/thoughts-on-mothertongue-based.html.

Ncoko, S.O.S., Osman, R. \& Cockroft, K., 2000, 'Codeswitching among multilingual learners in primary schools in South Africa: An exploratory study', International Journal of Bilingual Education and Bilingualism 3(4), 225-241. https://doi.org/ 10.1080/1367005000866770

Nicholas, H. \& Lightbown, P.M., 2008, 'Defining child second language acquisition defining roles for L2 instruction', in J. Philp, R. Oliver \& R. Mackey (eds.), Second language acquisition and the younger learner, pp. 27-51, John Benjamins Publishing, Amsterdam.

Nongogo, N., 2007, 'Mina "ngumZuluphaqa" language and identity among grade 9 learners at a private desegregated high school in South Africa', English Academy Review 24(2), 42-54. https://doi.org/10.1080/101317501452295

Owen-Smith, M., 2010, The language challenge in the classroom: A serious shift in thinking and action is needed, viewed 03 August, from https://hsf.org.za/ publications/focus/focus-56-february-2010-on-learning-and-teaching/thelanguage-challenge-in-the-classroom-a-serious-shift-in-thinking-and-action-isneeded.

Pearson, P.D. \& Stephens, D., 1994, 'Learning about literacy: A 30-year journey', in R.B. Ruddell, M.R. Ruddell \& H. Singer (eds.), Theoretical models and processes of reading, 4 th edn., pp. 22-42, International Reading Association, Newark, DE.
Plüddemann, P., 2010, Home-language based bilingual education: Towards a learnercentred language typology of primary schools in South Africa, Occasional Paper No. 32, PRAESA, University of Cape Town.

RSA, 1996, Constitution of the Republic of South Africa, Act 108 of 1996, Government Printer, Pretoria.

Setati, M. \& Adler, J., 2000, 'Between languages and discourses: Language practices in primary multilingual mathematics classrooms in South Africa', Educational Studies in Mathematics 43, 243-269. https://doi.org/10.1023/A:1011996002062

Slabbert, S. \& Finlayson, R., 2000, “'I'm a cleva!”: The linguistic makeup of identity in a South African urban environment', International Journal of the Sociology of Language 144, 119-135. https://doi.org/10.1515/ijsl.2000.144.119

Spaull, N., 2016, 'Disentangling the language effect in South African schools: Measuring the impact of 'language of assessment' in grade 3 literacy and numeracy', South African Journal of Childhood Education 6(1), a475. http://dx.doi. org/10.4102/sajce.v6i1.475

Spaull, N., 2017, The unfolding reading crisis: The new PIRLS 2016 results, viewed 05 December 2017, from https://nicspaull.com/2017/12/05/the-unfolding-readingcrisis-the-new-pirls-2016-results/.

Statistics South Africa (StatsSA), 2015, Census 2011: Income dynamics and poverty status of households in South Africa, Statistics South Africa, Pretoria.

Stoop, C., 2017, 'Children's rights to mother-tongue education in a multilingual world: A comparative analysis between South Africa and Germany', PER/PELJ 20, 1-35. https://doi.org/10.17159/1727-3781/2017/v20n0a820

Taylor, S. \& Coetzee, M., 2013, Mother-tongue classrooms give a better boost to English study later, viewed 25 April 2019, from https://mg.co.za/article/2013-1018-mother-tongue-classrooms-give-a-better-boost-to-english-study-later.

Trudgill, P., 1974, The social differentiation of English in Norwich, Cambridge University Press, Cambridge.

Trudell, B., Dowd, A.J., Piper, B. \& Bloch, C., 2012, Early grade literacy in African classrooms: Lessons learned and future directions, viewed 14 April 2016 from http://www.adeanet.org/triennale/Triennalestudies/subtheme1/1_5_04_ TRUDELL_en.pdf.

UNESCO, 2008b, Mother tongue instruction in early childhood education: A selected bibliography, UNESCO, Paris.

UNESCO, 2008a, Mother tongue matters: Local language as a key to effective learning, UNESCO, Paris.

Van Staden, S., Bosker, R. \& Bergbauer, A., 2016, 'Differences in achievement between home language and language of learning in South Africa: Evidence from prePIRLS 2011', South African Journal of Childhood Education 6(1), a441. https://doi. org/10.4102/sajce.v6i1.441

Webb, V., 2009, 'The politics of standardising Bantu languages in South Africa', Language Matters 41(2), 157-174. https://doi.org/10.1080/10228195.2010.500674

Welch, T., 2012, 'Why mother tongue literacy isn't working: Policy, pedagogy, parents, and publishing', guest address at the Annual General Meeting of the Witwatersrand Council on Education, Wits School of Education, 09 October. 